\title{
TASKS FOR SERVICE MODULARIZATION PLANNING
}

\author{
Ilona SKAČKAUSKIENE்(D), Jurga VESTERTE் (1D * \\ Vilnius Gediminas Technical University, Faculty of Business Management, \\ Management Department, Vilnius, Lithuania
}

Received 20 May 2020; accepted 17 August 2020

\begin{abstract}
Service modularization is gaining increasing attention from scholars and practitioners. However, it must be noted that the essence of service modularization is still not well understood, and its purposefulness of practical application has not yet been well explored. This conceptual paper presents the results of ongoing research addressing service modularization planning issues. The study examines the relationships between the premises and the outcomes of service modularisation. Based on the obtained results, the authors provide the purpose statement for service modularisation. Further, the work outlines the activities that are critical to planning as a management function, analyses their content in the context of service modularization, and identifies the problems that require management decisions. The paper employs comparative analysis, systemic analysis, abstraction, synthesis, abductive reasoning for achieving the research results.
\end{abstract}

Keywords: service modularization, service planning, planning decisions, service quality, service customization, service standardization.

JEL Classification: M11.

\section{Introduction}

The potential benefits of a modular system (Skačkauskienè \& Vesterte, 2019b) - the variety of options, complexity management, lower system operating costs, and similar - drives the application of modular design to service delivery. However, despite the growing body of research, practical applications of modularity to services are relatively rare (de Mattos et al., 2019). One can agree with Geum et al. (2012) that the provider's choice to apply modularity to services may be limited, in particular, by the nature of the service. It is easier to modularize massservice than knowledge-intensive (professional) services. While other authors (Broekhuis et al., 2017; Nätti et al., 2017) consider that with the advancement of information and communication technologies, elements and subprocesses of knowledge-intensive service offerings can be standardized as well. Going deeper into the application of modularity to services and analyzing the empirical cases presented in the literature (de Mattos et al., 2019), one can observe that there is a tendency to streamline service sub-processes through their standardization, however, not achieving service flexibility or, in other words, it is not possible to customize services flexibly in the event of such need. Thus, modularity - the breakdown of the system into independent modules that can be flexibly reconfigured as needed and the creation of the necessary variability without cost increase - is not likely in most of the attempts to transform the service system. The possible reason for this issue lies in management decisions not considering the totality of the modularization premises. Consequently, the prerequisites for service modularization initiatives require a thorough theoretical examination - there must be a definite answer as to why to modularize services.

The purpose of this paper is to identify the tasks for modular service planning. The aim is achieved through 1) analysis of the premises of service modularization, theoretically reasoning the impact of service modularity on service profitability; 2) identification of essential modularization planning activities for service management decision making; 3 ) analysis of the content of these activities and the problems to be solved.

The paper employs the framework of conceptual research. It constitutes the combination of previous associated work of the authors and uses the obtained knowledge for answering the problem statement in service modularization planning domain. The research applies comparative analysis, systemic analysis, abstraction, synthesis, abductive reasoning for achieving the results.

${ }^{*}$ Corresponding author. E-mail: jurga.vesterte@vgtu.lt

Copyright () 2020 The Author(s). Published by Vilnius Gediminas Technical University.

This is an Open Access article distributed under the terms of the Creative Commons Attribution License (http://creativecommons.org/licenses/by/4.0/), which permits unrestricted use, distribution, and reproduction in any medium, provided the original author and source are credited. 


\section{Rationale for service modularization}

According to McLaughlin (2010), regardless of the field or object of service, or the type of processes and technologies used to deliver the service, any service organization must consider the relationship between quality, cost and profitability when planning their delivery. The application of modular design to service requires a review of this dependency to determine how it will be affected and what the premises must be for service modularization to be sustained. It should be emphasized that the pursuit of economic benefits or profit is not the goal of all service organizations. It is important for public service organizations to maximize the value of the service without increasing costs, for social business service organizations to reconcile social impacts and benefits to society with economic benefits, and for sustainable service organizations to reconcile economic goals with social and environmental goals. Thus, the condition of maximizing profitability will not necessarily be central to finding justification for applying modular design to any type of service organization.

The service-profit chain model (Heskett et al., 2008) describes the relationship between service quality and profitability. According to it, a series of related factors determine the profitability of a service. Customer loyalty is one of the main drivers of service profitability, the most crucial factor of customer loyalty is customer satisfaction, which is determined by customer value or in other words, customer perceived quality of service. Customer value is created by satisfied, loyal, and productive employees. Smooth internal processes of the organization, effective technologies, compelling internal communication and similar ensure internal quality that defines employee satisfaction. Thus, service quality is understood in several ways in the service profit chain model: as perceived quality by customers and as meeting the requirements for doing the service or as the provider understands the service quality itself. The scientific literature (Anderson et al., 1997; Foster, 2017; Prentice et al., 2020) provides clarification on the interpretation and use of the multidimensional concept of quality in the context of services. They propose to distinguish two main categories: (1) quality that satisfies customer needs and (2) quality that is free from defects. The first category of quality in the context of services means that the services have necessary features, and their delivery is designed in such a way that ensures customer satisfaction. Anderson et al. (1997) propose to name this service quality as customization quality. The process of service customization creates this kind of quality, and this process roughly considered by the provider before the service is delivered. Customization is a situation where an individual customer receives a tailor-made solution to his or her problem or needs (Sundbo, 2002). The second category of service quality, the absence of defects, means that the service is reliable and guarantees that, regardless of the circumstances, customers will be able to receive the service without deviation from the positive experience. Anderson et al. (1997) suggest considering this quality as standardization quality. Standardization means creating appropriate conditions so that every time an identical product can be replicated (Sundbo, 2002).

Service standardization and the creation of the necessary premises for customization are components of service modularization (Skačkauskienè \& Vesterté, 2020). Service is standardized by refining the service offering and reducing its uncertainty, and by designing the subprocesses corresponding to the elements of the service offering and the interfaces between them, put differently, setting service standard. Service standardization also presumes service variability - the service offering or part of it is broken down into modules or new modules are created for existing parts of the service delivery sequence. The decoupling of the service into modules is done in such a way that different combinations of service can be made. These combinations evaluate customer involvement in service delivery and make sense to him/her by providing him/her specific benefits. Thus, service modularization implies qualities of both service customization and service standardization. Depending on the specifics of the service, one quality category may be expressed more and the other less. Sundbo (2002) notes that customizing a service seems to dictate that service input and service processes must also be unique and non-fixed. However, customization is done by combining standard service elements and standard process procedures so that each customer receives a customized service. Thus, even though it is a highly customized service, it still exhibits the standardization quality.

It is noteworthy that there is a kind of contradiction in the concept of service quality. A provider may find that it is beneficial to standardize and rationalize as much as possible to reduce defects or errors and minimize costs. However, rigid service standardization may not always be acceptable to a customer. Of course, the customer needs to be assured that a service runs smoothly and without errors, but he/she also needs exceptions or actions of customization. Therefore, the level of service quality will be the way customers perceive it and expose it through their satisfaction with the service. Notably, not all improvements in service quality lead to an increase in service profitability which, according to the service profit chain model mentioned above, increases if customer satisfaction is at a level sufficient to increase their loyalty. Wirtz and Lovelock (2018) also note that the relationship between service quality and profitability is not direct. They affirm that not all efforts to improve service quality are transformed into increasing profitability because not all quality improvements are perceived or essential to customers, and they do not tend to pay for them. Therefore, a provider needs to make those quality improvements that are likely to give the most significant effect on customer satisfaction. Empirical evidence also confirms this (Wirtz \& Zeithaml, 2018): providers that focus on delivering service in a way that delivers maximum customer satisfaction improve financial performance in the long run. 
Reduction of service delivery costs, when other conditions remain unchanged, increases service profitability. If a provider renders services through the more rational use of resources, it can expect a relatively better financial result. Meanwhile, improving service quality usually requires higher costs (Juran \& Godfrey, 1999). However, it pays off with increased service profitability and possible reduction in these costs of quality assurance in the long run. Thus, if the costs incurred in improving service quality result in a higher level of profitability in the long term than there would be no such profitability, without incurring those costs, it can be argued that the decision to incur these costs is rational. Identifying which costs of quality assurance will bring the expected customer satisfaction, which will translate into better financial results, is not a simple task and requires analysis of service productivity dynamics. Productivity shows how efficiently resources are transformed into end results (Anderson et al., 1997; Calabrese, 2012) and is calculated by the ratio of output to input. If productivity increases with increasing costs, it can be assumed that the costs have been expediently used to improve service quality. However, in practice, service productivity settings have different dimensions (Lehmann, 2019) and may reflect productivity content differently. For example, services are provided and consumed at the same time, which sometimes makes it challenging to capture the resources consumed, or it is not very straightforward to define the value of the output of the service process. Therefore, a provider must consider the specifics of the service and meet the challenges involved in order to calculate more accurately the performance of the service.

There is a paradox in the relationship between service quality and productivity, and their dynamics may vary. According to Wirtz and Lovelock (2018), in some cases, these dynamics may be positive (productivity increases, quality of service increases), others may be neutral (productivity increases, service quality unchanged) or negative (productivity increases, service quality decreases). Anderson et al. (1997) mathematically modelled the relationship between service quality and productivity and empirically confirmed that raising the level of service quality is likely to be inconsistent with productivity in two cases: 1) when the nature of the service results in strong customer satisfaction; 2) when it is difficult to maintain the levels of standardization and personalization at the same time and this is very costly.

In conclusion, if a service provider is modularizing service and seeking to improve service quality in the hope of excellent performance, it must balance customization and standardization to improve customer satisfaction, beyond the point where increasing service quality is no longer paying off. The service productivity must remain the same or increase as customer satisfaction grows. If such premises are met, then service modularization can be considered expedient. It is necessary to highlight that service modularization must be reasoned on increasing customer satisfaction. If customer satisfaction remains unchanged and only productivity increases, then this should be seen as a streamlining of service delivery processes through modular design rather than service modularization.

Figure 1 graphically presents the interconnection of service modularization premises. Service modularization is planned to take steps that standardize the elements of the service offering and the corresponding service subprocesses and provide the necessary variability of the service offering to customize the service. Standardization and customization will increase (marked with a + in the diagram) service quality, which is made up of customization.

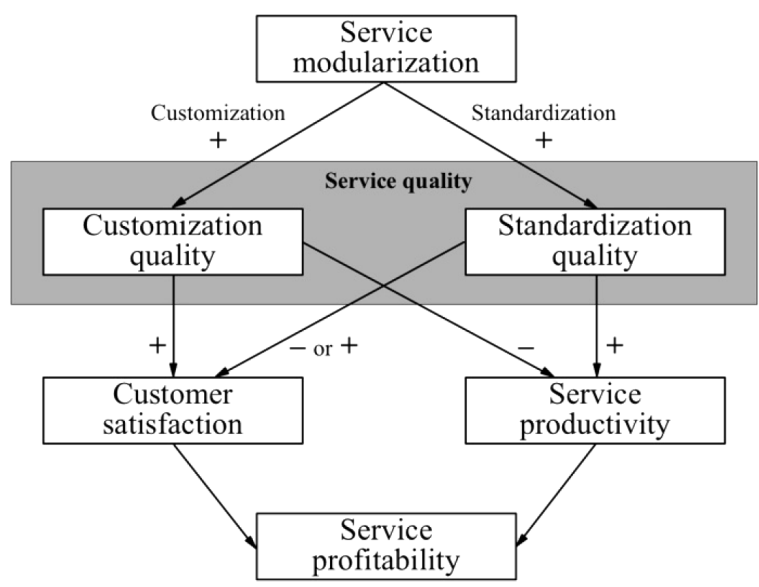

Figure 1. Interconnection of service modularization premises (source: created by authors)

quality and standardization quality. It is suggested to measure the improvement in service quality through modularization by the dynamics of customer satisfaction and service productivity. Both parameters depend on the components - customization quality and standardization quality. Customization quality increases $(+)$ customer satisfaction and decreases $(-)$ service productivity. Standardization quality can both lower or increase (- or $+)$ customer satisfaction and increase $(+)$ service productivity. The provider needs to discover a balance between customization that improves customer satisfaction and demand, and standardization that helps streamline processes, avoid errors and reduce costs, and follow that service profitability increases, or at least remains unchanged. If these conditions are met, service modularization can be considered justified.

\section{Identification of tasks for service modularization planning}

A classic of management theory, Gulick (2001 [1937]) one of the first introduces a description of what planning is as a management function. The researcher defined planning as an activity that outlines in broad the things and methods for doing to accomplish the stated goal. In modern management theory (S. C. Certo \& S. T. Certo, 2019; Cole \& Kelly, 2020), the function of planning is understood as making decisions about the goals set and how they will 
be achieved. Otherwise stated, planning involves many decisions or choices, all of which create the preconditions for achieving the goal. The content of these solutions is extensive, as planning can be examined from multiple perspectives within a hierarchy of time horizon or management level, choosing different planning objects or areas of an organization's activity. However, despite the broad content of the planning function, planning as a process is a sequence of actions and involves setting goals, developing assumptions and conditions, identifying alternatives for the course of actions, evaluating alternatives, choosing the best alternative. This logic is integrated into any planning and conveys the essence of planning as a management function.

When planning service modularization, it is essential to identify the elements of the service delivery system that will be affected by the intended changes. Services are diverse, and this dictates that their delivery systems consist of various components. However, according to Bitran and Pedrosa (1998), the elements of most existing service delivery systems can be divided into four main groups: 1) people; 2) service offering; 3) infrastructure; and 4) interfaces. The first group includes the customers and the employees, who in turn can be grouped into those with high contact intensity and those who have almost no contact with the customer. The content of the second group, the service offering, is rather complex (Skačkauskiene \& Vestertė, 2020). Nevertheless, Bitran and Pedrosa (1998) propose to classify the elements of this group according to the tangible and intangible attributes. The infrastructure group (Bitran \& Pedrosa, 1998) distinguishes three subgroups: 1) a subset of elements visible to the customer (service facilities, transport, uniforms, etc.); 2) a subset of physical elements that are invisible to the customer (technical facilities, tools, etc. required to perform the service); 3) a subgroup of technologies that distinguish between hard technology (equipment used), and soft technology (information systems, technological procedures and processes). According to Bitran and Pedrosa (1998), the interface group includes all possible interactions between a customer and a provider through any medium. Interactions are possible due to the interplay of the elements of the first group (people, service offering, infrastructure). From the viewpoint of the service delivery process (Skačkauskiene \& Vesterte, 2019a), these interactions correspond to service events, which occur when a customer's sequence of actions using their own resources to obtain service matches with the service delivery activities.

Service modularization affects many elements of the service delivery system, and its implementation requires significant organizational effort, resource mobilization, and alignment with the organization's strategic planning. Service delivery system realignment according to modular principles is accomplished through four major phases (1) analysis, (2) design and development, (3) implementation, (4) maintenance and support - which are consistent with the engineering project life cycle (Blanchard \& Blyler,
2016). Each phase has content specific to service modularization (Table 1).

Table 1. Content of service modularization phases (source: created by authors)

\begin{tabular}{|l|l|}
\hline \multicolumn{1}{|c|}{ Phase } & \multicolumn{1}{c|}{ Content } \\
\hline Analysis & $\begin{array}{l}\text { Formulation of goals for the intended } \\
\text { changes. }\end{array}$ \\
\hline $\begin{array}{l}\text { Design and } \\
\text { development }\end{array}$ & $\begin{array}{l}\text { Service and its sub-processes redesign } \\
\text { based on modular design principles, } \\
\text { considering the requirements, conditions, } \\
\text { tasks formulated in the analysis phase. } \\
\text { Necessary developments. }\end{array}$ \\
\hline Implementation & $\begin{array}{l}\text { Implementation of designed and } \\
\text { developed changes. }\end{array}$ \\
\hline
\end{tabular}

Essential activities in service modularization that are critical for planning as a management function can be identified (Figure 2). The first step is to carry out analytical activities related to planning to formulate goals and objectives: 1) analysis of customer satisfaction; 2) analysis of capabilities to service modularization; 3) analysis of feasibility for service modularization. The analysis of customer satisfaction must seek to identify levels of customization and standardization. The capability analysis reveals whether a provider has the necessary capabilities to undertake service modularization. Salvador et al. (2009) argue that such capabilities include: 1 ) the ability to identify service attributes that allow for customized offers; 2) knowledge and necessary practices for designing flexible delivery processes; 3 ) the ability to help clients identify their needs and offer the solutions they need while reducing the burden of choice. The provider has such abilities if it follows customer-centricity practices. The feasibility study needs to clarify which service modularization strategy is suitable for the nature of the services and the dominated processes (Carlborg \& Kindström, 2014), what technologies are available to standardize and automate the delivery processes, the demand of resources for design and implementation. Service redesign is closely related to the specificity of the service and the technological aspects of its delivery, which require both professional specialization and good service marketing knowledge. Service redesign can be done following the systems engineering discipline and its methodology.

When considering service modularization from a managerial perspective, it is important to highlight those activities that are relevant to service modularization planning. From a systemic point of view, the realignment of service delivery must be initiated by management decisions stemming from goal formulation, analysis of customer needs, and analysis of feasibility for service modularization. They form the basis for a set of assumptions and conditions for service modularization. Alternative solutions for service offering (product) and service delivery (process) as an outcome from service redesign must be evaluated by management to identify the best ones that meet the goals and objectives of service modularization. 
Selected service offering and service delivery solutions are implemented through initiating reorganization of the service delivery system structure, making necessary changes to the system element groups (people, service offering, infrastructure, interfaces or interactions). Measuring achievement of goals is to be considered as part of control function, but it is very closely linked to the planning function as the necessary criteria or indicators have to be defined at the goal formulation stage. The formulation of service modularization goal reveals what these criteria and indicators should endeavor. The aim of service modularization is to combine the service customization quality and standardization quality so that customer satisfaction increases while service productivity remains unchanged or increases. Thus, the measurement of goal achievement requires the development of a set of indicators, consisting of the measurement of customer satisfaction, which integrates parameters of customization and standardization qualities, and the measurement of service productivity.

Once service modularization planning activities have been identified, it is possible to formulate their tasks in a logical way (Table 2).

In order to fulfil the stated tasks of planning activities, it is necessary to solve the identified problems, which require the formation of a methodological foundation for finding solutions. This assignment will be pursued during further research on this topic.

\section{Conclusions}

In addition to standardizing the elements of a service offering and the corresponding service sub-processes, service modularization involves the creation of meaningful variation to the customer and allows customization during

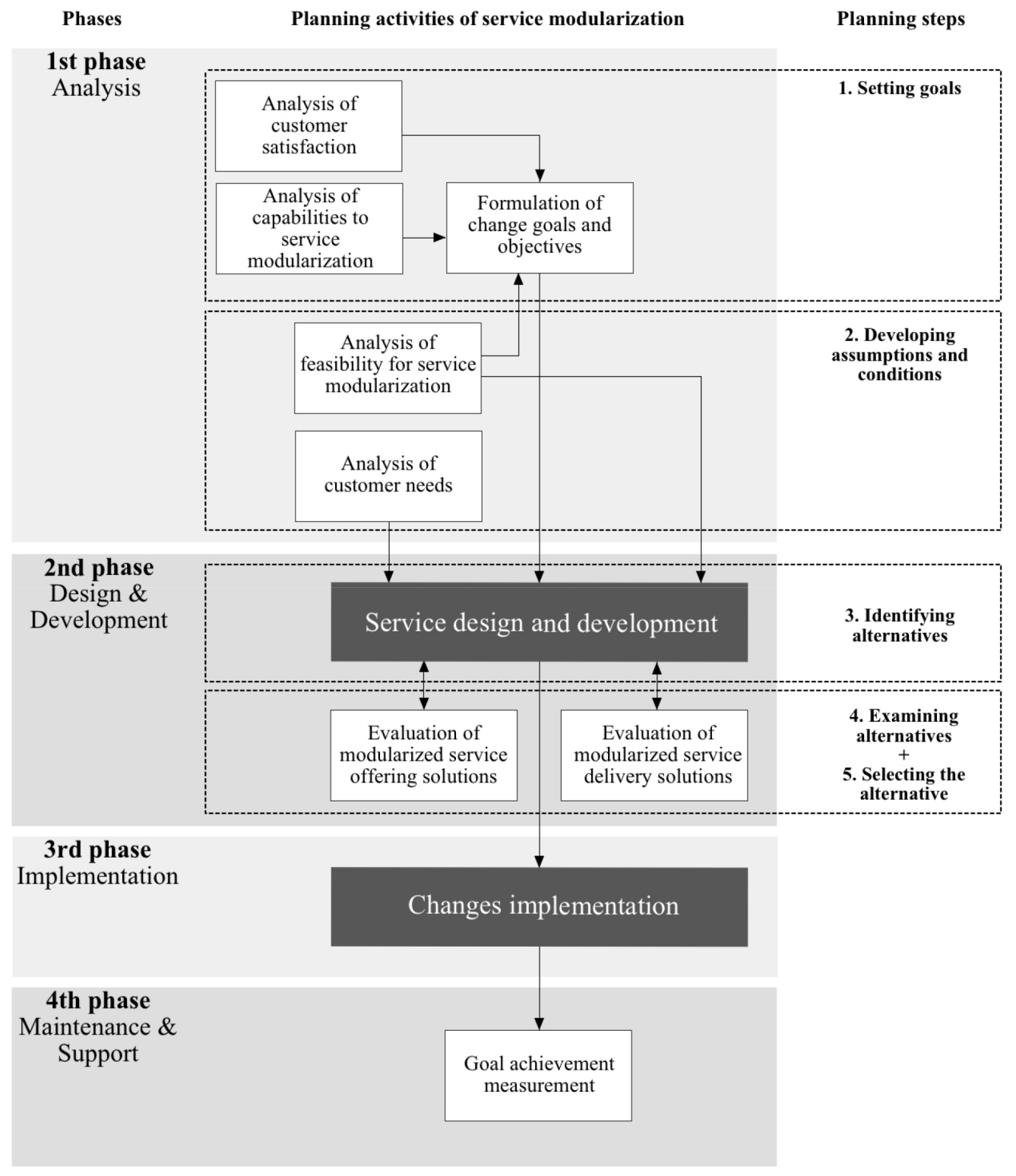

Figure 2. Planning activities of service modularization (source: created by authors) 
Table 2. Tasks and problems while planning for service modularity (source: created by authors)

\begin{tabular}{|c|c|c|}
\hline Planning activity & Activity tasks & Problems to solve \\
\hline $\begin{array}{l}\text { Analysis of customer } \\
\text { satisfaction }\end{array}$ & $\begin{array}{l}\text { Identify the levels of service customization and } \\
\text { standardization and their impact on customer } \\
\text { satisfaction. }\end{array}$ & $\begin{array}{l}\text { How to operationalize qualitative evaluations } \\
\text { into criteria for evaluating achievement of service } \\
\text { modularization goals? }\end{array}$ \\
\hline $\begin{array}{l}\text { Analysis of capabilities to } \\
\text { service modularization }\end{array}$ & $\begin{array}{l}\text { Determine the current level of service provider's } \\
\text { capabilities to modularize service and necessary } \\
\text { capabilities to be acquired. }\end{array}$ & $\begin{array}{l}\text { How to determine the capabilities required, and } \\
\text { what criteria are used to determine their current } \\
\text { level? }\end{array}$ \\
\hline $\begin{array}{l}\text { Analysis of feasibility for } \\
\text { service modularization }\end{array}$ & $\begin{array}{l}\text { Define a modularization strategy appropriate to the } \\
\text { nature of the service. Identify opportunities and } \\
\text { constraints to use technological, financial, human } \\
\text { resources and outsourcing. }\end{array}$ & $\begin{array}{l}\text { What is the basis for defining a modularization } \\
\text { strategy appropriate to the nature of the service? }\end{array}$ \\
\hline $\begin{array}{l}\text { Formulation of change } \\
\text { goals and objectives }\end{array}$ & $\begin{array}{l}\text { Identify the goals and objectives of changes related } \\
\text { to service modularization. }\end{array}$ & $\begin{array}{l}\text { What indicators can be used to reflect the set } \\
\text { goals and objectives? }\end{array}$ \\
\hline $\begin{array}{l}\text { Analysis of customer } \\
\text { needs }\end{array}$ & $\begin{array}{l}\text { Identify service characteristics as key to } \\
\text { customization and standardization. }\end{array}$ & $\begin{array}{l}\text { What are the criteria for defining the key } \\
\text { attributes to create service variability and the } \\
\text { elements of the service for which standardization } \\
\text { customers would be neutral? }\end{array}$ \\
\hline $\begin{array}{l}\text { Evaluation of } \\
\text { modularized service } \\
\text { offering solutions }\end{array}$ & $\begin{array}{l}\text { Determine whether the solution meets customer } \\
\text { requirements and whether standardized modules } \\
\text { will allow for the required variation in service } \\
\text { customization that will transmute to the increase in } \\
\text { customer satisfaction. }\end{array}$ & $\begin{array}{l}\text { What are the criteria for evaluating a proposed } \\
\text { service offering (product) solution? }\end{array}$ \\
\hline $\begin{array}{l}\text { Evaluation of } \\
\text { modularized service } \\
\text { delivery solutions }\end{array}$ & $\begin{array}{l}\text { Determine whether the proposed service delivery } \\
\text { standardization solution is rationally designed and } \\
\text { whether it will deliver a customized service offering } \\
\text { while maintaining or increasing productivity level. }\end{array}$ & $\begin{array}{l}\text { What are the criteria for evaluating a proposed } \\
\text { service delivery (process) solution? }\end{array}$ \\
\hline $\begin{array}{l}\text { Goal achievement } \\
\text { measurement }\end{array}$ & $\begin{array}{l}\text { Determine the achievement-level of service } \\
\text { modularization goals. }\end{array}$ & $\begin{array}{l}\text { What set of indicators reflects the level of } \\
\text { achievement? }\end{array}$ \\
\hline
\end{tabular}

service delivery. Unfortunately, in practical applications of service modularization, there is only one component of service modularization, standardization, which manifests itself in the rationalization of service delivery processes and does not take customer satisfaction into account. Such service system realignments should only be considered as streamlining of delivery processes using modular design, not service modularization.

In order to determine, what aspects need to be considered for a service modularization to be justified, the coherence of premises of service modularization was analyzed. It was stated that service modularization is expedient when a provider handles to combine customization quality and standardization quality so that customer satisfaction increases and leads to higher revenue while service productivity remains unchanged or increases.

Planning activities play an essential role in rationality and fluidity of service modularization. They support the formulation of objectives, necessary conditions, and requirements for service realignment on a modular basis. The research identified eight such activities: 1) analysis of customer satisfaction; 2) analysis of capabilities to service modularization; 3 ) analysis of feasibility for service modularization; 4) formulation of change goals and objectives; 5) analysis of customer needs; 6) evaluation of modularized service offering solutions; 7) evaluation of modularized service delivery solutions; 8) goal achievement measurement. After the analysis of these planning activities, their tasks were clarified, and problematic issues requiring the formation of a methodological basis were identified. Further research will investigate them. From a practical point of view, the creation of such a decision support instrument would make it possible to make rational decisions when planning for service modularization.

\section{References}

Anderson, E. W., Fornell, C., \& Rust, R. T. (1997). Customer satisfaction, productivity, and profitability: Differences between goods and services. Marketing Science, 16(2), 129-145. https://doi.org/10.1287/mksc.16.2.129

Bitran, G., \& Pedrosa, L. (1998). A structured product development perspective for service operations. European Management Journal, 16(2), 169-189. https://doi.org/10.1016/S0263-2373(97)00086-8

Blanchard, B. S., \& Blyler, J. E. (2016). System engineering management (5 ed.). John Wiley \& Sons, Inc. https://doi.org/10.1002/9781119178798

Broekhuis, M., van Offenbeek, M., \& Eissens-van der Laan, M. (2017). What professionals consider when designing a modular service architecture? International Journal of Operations \& Production Management, 37(6), 748-770. https://doi.org/10.1108/IJOPM-05-2015-0306

Calabrese, A. (2012). Service productivity and service quality: A necessary trade-off? International Journal of Production Economics, 135(2), 800-812. https://doi.org/10.1016/j.ijpe.2011.10.014 
Carlborg, P., \& Kindström, D. (2014). Service process modularization and modular strategies. Journal of Business \& Industrial Marketing, 29(4), 313-323.

https://doi.org/10.1108/JBIM-08-2013-0170

Certo, S. C., \& Certo, S. T. (2019). Modern management: concepts and skills, global edition (15 ed.). Pearson Education.

Cole, G. A., \& Kelly, P. (2020). Management theory and practice ( 9 ed.). Cengage Learning EMEA.

de Mattos, C. S., Fettermann, D. C., \& Cauchick-Miguel, P. A. (2019). Service modularity: Literature overview of concepts, effects, enablers, and methods. The Service Industries Journal. https://doi.org/10.1080/02642069.2019.1572117

Foster, S. T. (2017). Managing quality: integrating the supply chain (6 ed.). Pearson Education, Inc.

Geum, Y., Kwak, R., \& Park, Y. (2012). Modularizing services: A modified HoQ approach. Computers \& Industrial Engineering, 62(2012), 579-590. https://doi.org/10.1016/j.cie.2011.11.006

Gulick, L. (2001 [1937]). Notes on the theory of organization. In J. M. Shafriz \& J. S. Ott (Eds.), Classics of organization theory (5 ed., pp. 79-87). Harcourt College Publishers.

Heskett, J. L., Jones, T. O., Loveman, G. W., Sasser, E., \& Schlesinger, L. A. (2008). Putting the service-profit chain to work. Harvard Business Review, 2008(July-August). https://hbr. org/2008/07/putting-the-service-profit-chain-to-work

Juran, J. M., \& Godfrey, A. B. (1999). Juran's quality handbook (5 ed.). McGraw-Hill Company, Inc.

Lehmann, C. (2019). Exploring service productivity: Studies in the German airport industry. Springer Gabler. https://doi.org/10.1007/978-3-658-23036-4

McLaughlin, S. (2010). Service operations and management. In G. Salvendy \& W. Karwowski (Eds.), Introduction to service engineering (pp. 295-315). John Wiley \& Sons, Inc. https://doi.org/10.1002/9780470569627.ch14
Nätti, S., Ulkuniemi, P., \& Pekkarinen, S. (2017). Implementing modularization in professional services: The influence of varied knowledge environments. Knowledge and Process Management, 24(2), 125-138. https://doi.org/10.1002/kpm.1538

Prentice, C., Lopes, S. D., \& Wang, X. (2020). The impact of artificial intelligence and employee service quality on customer satisfaction and loyalty. Journal of Hospitality Marketing \& Management, 20(7). https://doi.org/10.1080/19368623.2020.1722304

Salvador, F., Holan, P. M. d., \& Piller, F. (2009). Cracking the code of mass customization. Sloan Management Review, 2009(Spring), 71-78. https://sloanreview.mit.edu/article/cracking-the-code-of-mass-customization/

Skačkauskienè, I., \& Vestertè, J. (2019a, May 9-10). Discourse on service modularity: Investigating service delivery process. In Paper presented at the International Scientific Conference "Contemporary Issues in Business, Management and Economics Engineering'2019”. Vilnius, Lithuania. https://doi.org/10.3846/cibmee.2019.060

Skačkauskienė, I., \& Vestertė, J. (2019b). Modulinio projektavimo taikymo paslaugoms problematika [Problematic of service modularisation]. Mokslas - Lietuvos ateitis / Science - Future of Lithuania, 11, 1-9. https://doi.org/10.3846/mla.2019.9195

Skačkauskienė, I., \& Vestertè, J. (2020). Peculiarities of planning for service modularity. International Journal of Learning and Change. https://doi.org/10.1504/IJLC.2020.10028495

Sundbo, J. (2002). The service economy: Standardisation or customisation? Service Industries Journal, 22(4), 93-116. https://doi.org/10.1080/714005099

Wirtz, J., \& Lovelock, C. (2018). Essentials of services marketing (3 ed.). Pearson Education.

Wirtz, J., \& Zeithaml, V. (2018). Cost-effective service excellence. Journal of the Academy of Marketing Science, 46(1), 59-80. https://doi.org/10.1007/s11747-017-0560-7 